\title{
Construction problems on the karstified limestone tuffs of Condeixa, central Portugal: a case study
}

\author{
M. QUINTA FERREIRA ${ }^{1, \star}$ and J. L. VELHO ${ }^{2}$ \\ ${ }^{1}$ Department of Earth Sciences, University of Coimbra, Portugal; e-mail: mqf@dct.uc.pt \\ ${ }^{2}$ Department of Geosciences, University of Aveiro, Portugal; e-mail: jvelho@clix.pt
}

\begin{abstract}
During the excavations for the foundations of a three storey building on the limestone tuffs of Condeixa, Central Portugal, a large dissolution fissure and smaller dissolution voids were found. Since the area has never been the subject of engineering geology investigation, it was decided to evaluate the risk associated with the construction of the building. These limestone tuffs were formed in a continental environment by the precipitation of calcite carried by the water coming from the large limestone body in the east. The precipitated calcite mixed with the terrigenous materials and around trunks and leaves of plants, originating a very heterogeneous and porous ground, which is characteristic of limestone tuffs. The study started with a detailed geological survey followed by a large number of destructive drillings, located essentially under the pad foundations. The results revealed several karstic cavities with serious problems for the building foundations and the structure, and many smaller dissolution cavities, often filled with clayey soils. The ground treatment solutions used included, dental cleaning, filling with concrete or granular material the dissolution structures accessible at the level of the foundation, reinforcement of the footing and the structure of the building and adding a continuous foundation beam to hold the foundations together. The cost of the engineering geology study, site investigation, ground treatment, and the reinforcement of the foundation and building, increased the total construction cost from $2 \%$, at the design stage, to $4.8 \%$.
\end{abstract}

Key words. construction problems, foundation treatment, karst, limestone tuffs, site investigation.

\section{Introduction}

The construction of a three storey building in Condeixa, central Portugal, required a few meters of excavation to lower the construction level to build the main entrance on the street level. During the early stage of the excavation a large dissolution structure and smaller dissolution cavities were found. Since the area had never been subjected to engineering geology investigation, it was decided to study the site to evaluate the extent of the karst, its characteristics and the problems that the karstic limestone tuffs could cause to the building under construction (Quinta Ferreira, 1998).

^ Corresponding author: Prof. Mário Quinta Ferreira, Departamento de Ciências da Terra, Universidade de Coimbra, 3000-272 Coimbra, Portugal. 


\section{Geology}

\subsection{OUTCROPS}

Detailed geological reconnaissance investigations revealed that the Condeixa region (Figure 1) is mainly composed of Jurassic age limestone in the east and south, Cretaceous age sandstones and clays in the west and limestone tuffs in the transitional area overlying the sandstones and clays. The limestone tuffs of Quaternary age are probably around 350,000 years old (according to Gaida e Radtke, 1983, referred by Soares et al., 1997).

The whole formation of the limestone tuffs occupies an area around $10 \mathrm{~km}^{2}$, with a thickness of about $30 \mathrm{~m}$. The outcrops have irregular shapes, being essentially located on geomorphologic platforms. The limestone tuffs have three main outcrops in the area: (1) the larger is in the south, between Conimbriga (Roman ruins), Condeixa-a-Velha and Condeixa-a-Nova; (2) in the middle, between Eira Pedrinha and Orelhudo; (3) in the north, between Vila Nova and Cernache, where the present case study is located (Figure 1).

\subsection{TUFFS FORMATION AND CHARACTERISTICS}

The formation process of the limestone tuffs of Condeixa is attributed to the chemical precipitation of calcite carried by drain waters from the large limestone

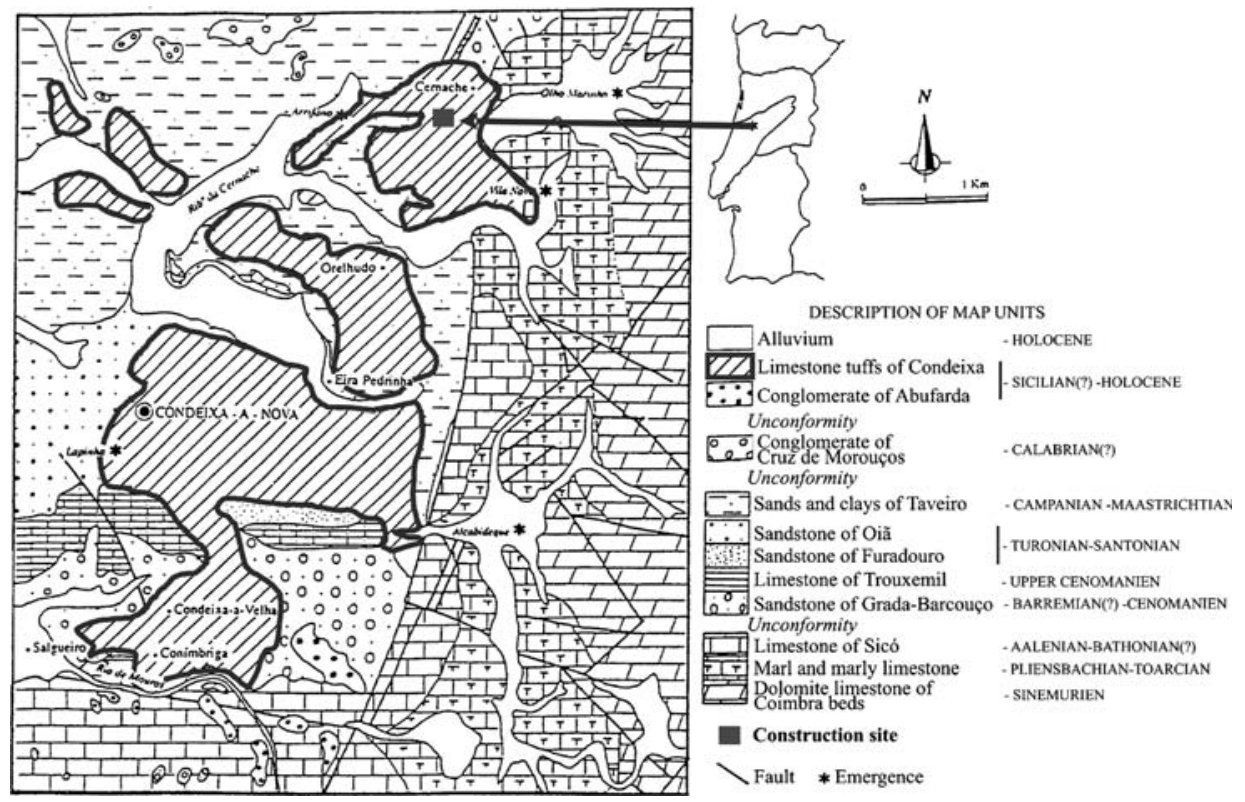

Figure 1. Distribution of the limestone tuffs in the region of Condeixa and location of the construction site (modified from Soares et al., 1997). 
body in the east. As the calcite precipitate it mixes with the surrounding materials, creating a very heterogeneous body. Posterior fracturing and karstic processes added more anisotropy to the limestone tuffs developing unusual structures.

The limestone tuffs of Condeixa contain four facies, according to Soares et al. (1997): clayey tuff; accumulation tuff; conglomerate tuff; undulated or in cascade tuff.

The clayey tuff has a brown-yellow to grey colour and is the dominant facies in the area. The accumulation tuff is quite rich in plant fossils, resulting from the precipitation of calcite around leaves and trunks of bushes, grass and even trees. The conglomerate tuff was formed by the precipitation of calcite around clastic particles. In Figure 2, an aspect of the accumulation and conglomerate tuffs are shown in a slope cut $20 \mathrm{~m}$ away from the site. The undulated and in cascade tuff was formed near cascades and springs. The heterogeneity of the limestone tuffs created some difficulty in the evaluation of the distribution of the different facies.

The limestone tuffs of Condeixa show karstification, with small lapias, caves and springs which are linked with the drainage network moulding the surface of the tuffs. Small karstic caves are known in the area. One of them is known by the name of "Forno da Moura" (oven of the Moor) and the local people say that "... since the time of the great-grandmother of their grandmother the singing of the Moor is heard from time to time". Our interpretation of this legend is that the sound of the water running through the karstic system, would produce melodic sounds, sounding like a song to local inhabitants.

\subsection{SITE GEOLOGY}

The site geology consists of three layers, separated by darker limits corresponding to ancient surfaces of exposure. From top to bottom in ascending order are (Figure 3):

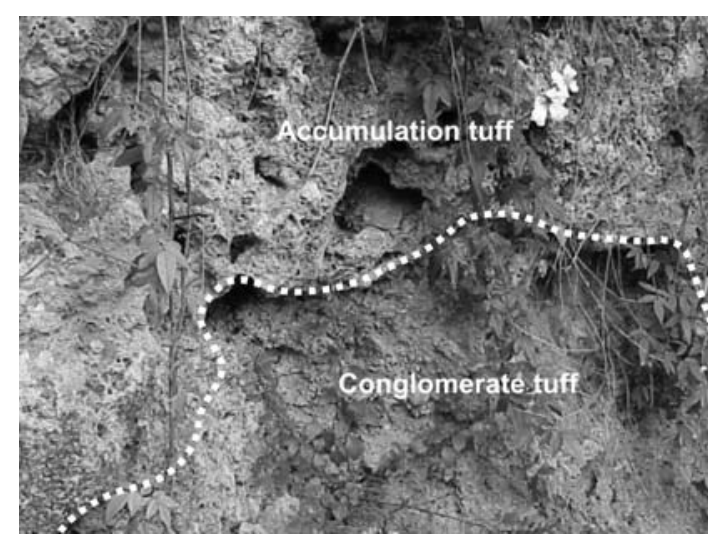

Figure 2. Aspect of the accumulation tuff and conglomerate tuff in an old cut, close to the site. The large voids on the accumulation tuff correspond to the trunks of plants surround by precipitated calcite. The erosive action of the water removed the clay usually filling the voids before exposure. 
cover soil (0.4-3.3 m thick); cover soils mixed with limestone tuffs (up to $4.6 \mathrm{~m}$ thick); limestone tuff (around $30.0 \mathrm{~m}$ thick). In Figure 3 the distribution of the three units identified on site are shown to be represented along the east and south surface walls of the excavation. The levels intended for the ground floor and the bottom of the excavation are also indicated.

The uppermost layer, the cover soil, has a dark brown to black colour, contains a high content of organic material and occasionally red brick fragments. This human made layer, has a flat surface, and was used for agricultural purposes.

The layer of cover soils mixed with limestone tuffs has a brown colour and makes the transition between the surface organic soils and the underlying limestone tuffs. The thickness of the layer increases towards the west.

The limestone tuffs are the bedrock, showing variable characteristics, depending on the distribution of the facies, the materials that were included in the tuffs, the karstic structures and the porosity of the rock. On the western end of the area (block 1 of the building) the clayey tuffs are dominant, having a darker colour, mainly brownish, and a high content of clay. On the eastern end of the area (block 2 of the building) the tuffs are essentially of an accumulation type, showing light colours, mainly yellowish, having high calcium carbonate content and a low clay content. The peculiar mode of origin of the tuff, resulting from the precipitation of calcium carbonate around the surrounding objects, generated an enormous quantity of small channels and tubes and abundant fossil prints of plants, mainly leaves and stems. The leaf prints usually show the well defined nervures. The thickness of the tubes vary form a few millimetres to several centimetres.

The main fractures on the tuffs are roughly oriented NNE-SSW. Less important fractures are oriented NE-SW. The directions of these fractures are also found in the regional pattern of fractures, affecting mainly the older Jurassic rocks (Figure 1). The direction of the fractures controlled the development of the planar karstic structures that we designate as planar dissolution structures.

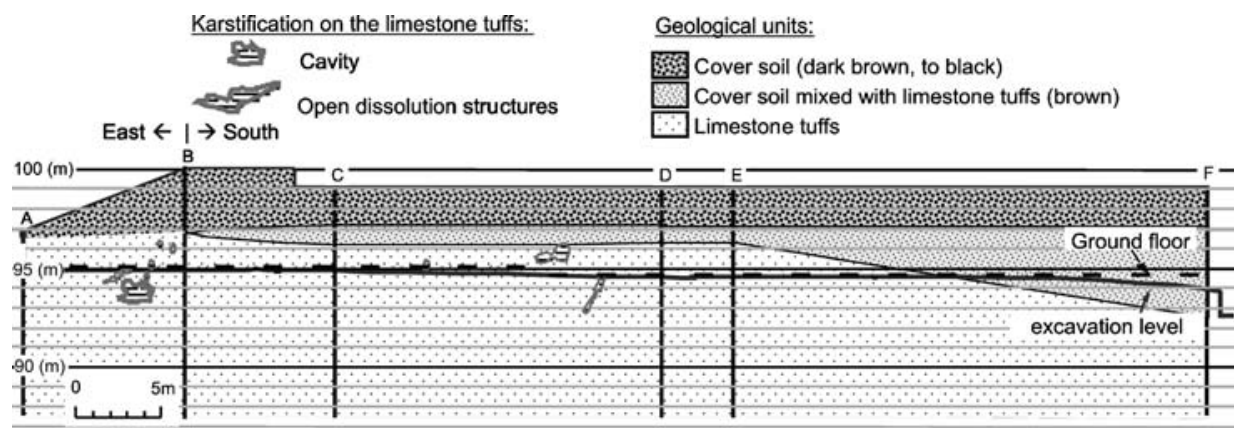

Figure 3. Distribution of the three units identified along the east and south faces of the excavation. The level intended for the ground floor, the bottom of the excavation and the karstic structures identified during the first phase of investigation are presented. 


\section{Site Investigation}

\subsection{STUDY PROCEDURES AND PHASES}

The initial investigations of the site revealed several dissolution zones in the limestone tuffs already exposed by the excavation.

After verifying the importance and extent of the problem, it was decided that the construction could only be continued after a detailed study of the foundation ground. As the building structure was of a small dimension, the cost of the site investigation and the solutions for the treatment of the foundation became a great concern immediately. All the work done afterwards tried to obtain the maximum information regarding the karstic process, in order to evaluate the need to redesign the foundations, and eventually the structure of the building.

For the investigation of the conditions of the ground where the foundations were to be constructed it was considered necessary to follow some guidelines (Quinta Ferreira, 1998): (a) dig some reconnaissance pits at selected locations; (b) remove all the soils above the limestone tuffs in order to locate the upper karstic structures; (c) clean all the soils and rock fragments filling the karstic cavities; (d) map and describe all the karstic structures; (e) evaluate the need for additional geotechnical investigation, mainly in the areas where the foundations will induce higher stress; (f) execute additional site investigation and $(\mathrm{g})$ choose the best solutions for the treatment of the karstic structures.

To achieve the best management of the site investigation, adjusted to the construction schedule and work space available on the construction site, the engineering geology study was divided into three main phases: Phase 1 - Geological survey of the site and foundation treatment of area ABCI of block 2 (Figure 4). Phase $2-$ Destructive drilling in block 2 and foundation treatment of area CDHI. Phase 3 Destructive drilling and foundation treatment in block 1 (area DEFGH). The results revealed several important karstic structures with serious problems for the building foundation and structure, and many smaller dissolution cavities, sometimes filled with clayey soils (Quinta Ferreira, 1999).

The destructive drillings were executed in two campaigns, as already mentioned, in a total of 49 drillings. They were done by roto-percussion using a hydraulic pressure of $255-276 \mathrm{kPa}$ and an air pressure between 800 and $1400 \mathrm{kPa}$ depending on the depth. The recorded drilling speed was from $0.73 \mathrm{~m} / \mathrm{min}$ up to $2.29 \mathrm{~m} / \mathrm{min}$, with the most frequent values between 1 and $1.5 \mathrm{~m} / \mathrm{min}$.

In the first campaign (Phase 2) drill-holes 1-18 were executed on the area CDHI of block 2. In the second campaign (Phase 3) drill-holes 19-49 were executed in block 1. The total length of drilling was $290 \mathrm{~m}$ with an average depth of $5.9 \mathrm{~m}$ per drill-hole. The drill-holes 20 and 21 were the deepest with a depth of $7.3 \mathrm{~m}$, and the shallowest, drill-hole 10, had a depth of $2.15 \mathrm{~m}$. Most of the drillings were executed on the vertical position, but because the need to intersect the karstic structures or to difficulties on the accessibility at a few places, some inclined drillings were executed 


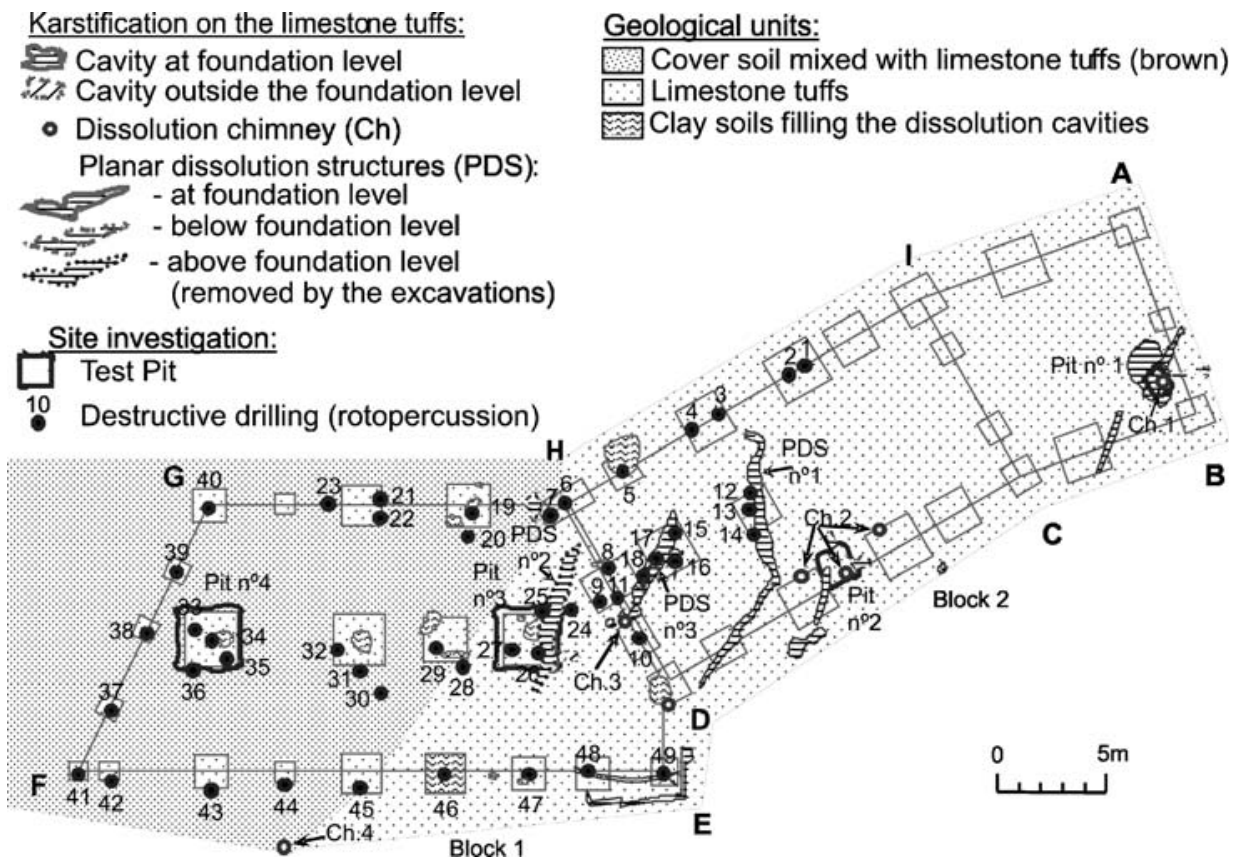

Figure 4. Location of the destructive drillings and of the karstic structures identified close to the level of foundation.

(drill-holes 16 and 17 were inclined $67^{\circ}$, drill-hole 18 was inclined $55^{\circ}$ and drill-hole 49 was inclined $45^{\circ}$ ).

During the drillings the parameters recorded were: the lithology, the presence of voids, the sudden reduction of pressure or the drop of the drill rods, the drilling speed and the moisture content. In Figure 5 a few simplified logs are presented.

The soils identified were fill, organic soil mixed with tuff, clayey tuff (brown or yellow), clay and also hard limestone.

\subsection{PHASE 1}

The works started with the excavation of the whole area above the level of the foundation of the building, approximately level $95 \mathrm{~m}$ (Figure 3).

Due to the sequence of operations during the construction process, the first area to be constructed was area ABCI of block 2. The dental cleaning and foundation treatment of area $\mathrm{ABCI}$ was done without the execution of mechanical investigation because it was decided, to continue the construction works in this area, immediately after the results of the surface reconnaissance.

The detailed geological investigation and mapping carried out in the first phase of the study revealed the three units already described in the local geology, which are represented in Figure 3. 

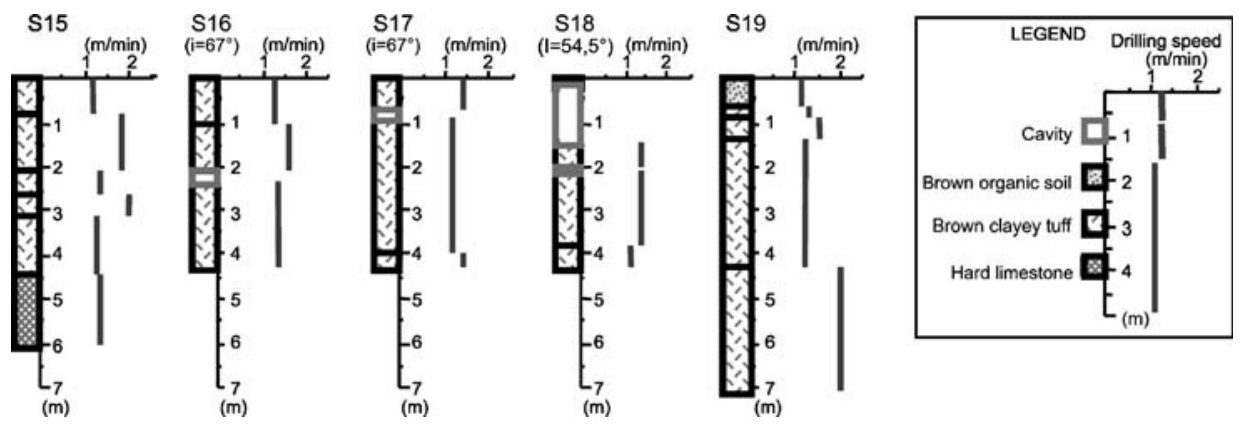

Figure 5. Example of a few simplified logs of the destructive drillings.

During this first phase of the study, the main tasks undertaken were: geological reconnaissance of the site with detailed geological mapping of the excavated surfaces (floor and walls); execution of four pits in the foundation; dental cleaning of karstic spots and mapping; foundation treatment of area ABCI of block 2, with dental cleaning of the karstic structures and filling of the voids with concrete; foundations reinforcement and construction of the building in area ABCI of block 2 .

\subsection{PHASE 2}

Initially the execution of detailed mapping was proposed, after the dental cleaning of all the excavation surfaces, complemented with drilling with continuous coring, or alternatively destructive drilling, and investigation profiles with a Geo-Radar.

In the selection of the site investigation technique, the information that each technique would permit was considered, together with two other important aspects: the cost and the execution time needed.

The Geo-Radar was not used for two reasons. The excavation work for the footings in block 2 was already completed, creating a very irregular surface of the ground, causing significant difficulties in the execution and interpretation of the profiles, and also because the contractor could only start to execute the profiles two months later, a delay that was not acceptable for the construction schedule. The final decision was to carry out destructive drillings, because they had the best cost/benefit ratio to identify the presence of the karstic voids.

The main tasks done during phase 2 were: detailed geological mapping of the excavated surfaces; execution of 18 destructive drillings (nos. 1-18) in the footings location in block 2 (area CDHI of Figure 4); dental cleaning of voids; filling of voids and drill-holes with concrete or granular material; foundations reinforcement and construction of the building structure in area CDHI.

The brown clayey tuff is abundant, and was found in all the drillings. The yellow clayey tuff was only encountered at depths greater than $3 \mathrm{~m}$, by the drillings executed in the transition between block 1 and block 2 (drill-holes 5, 6, 7 and 9). The hard 


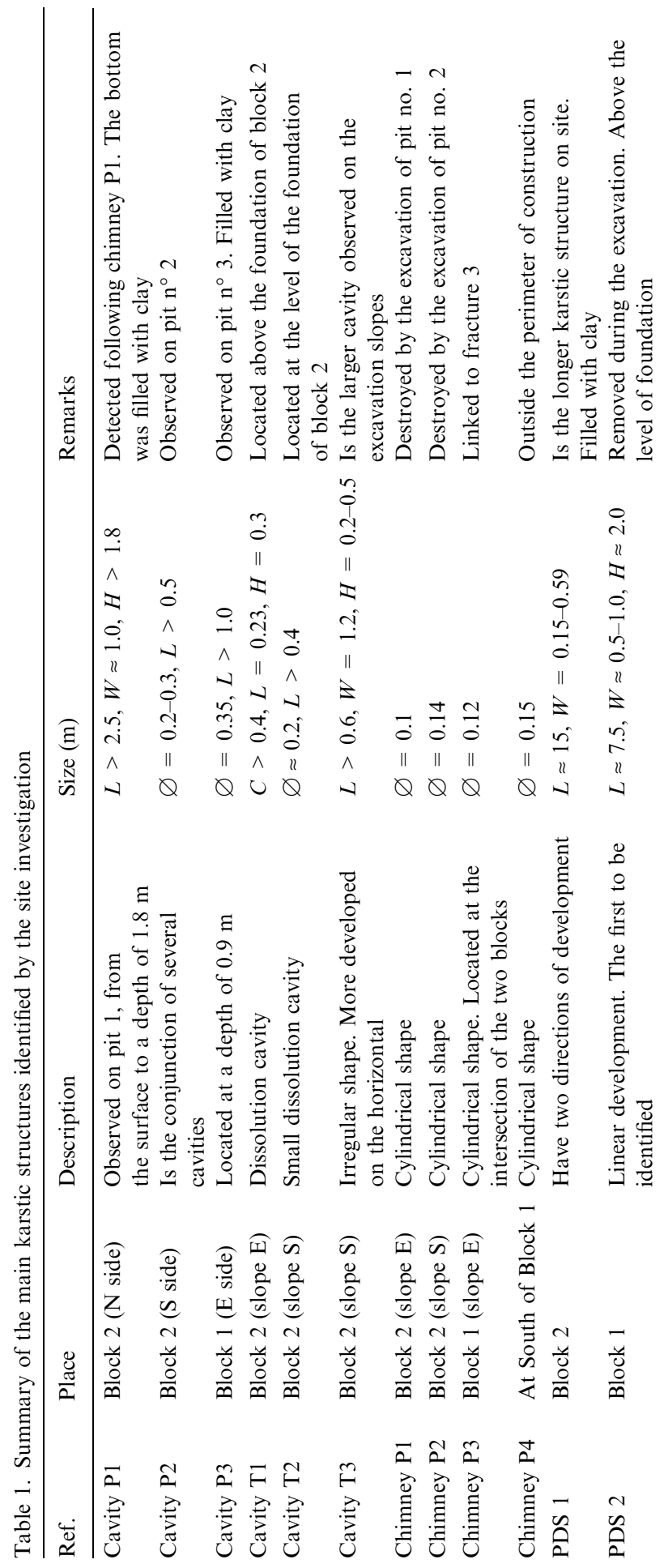




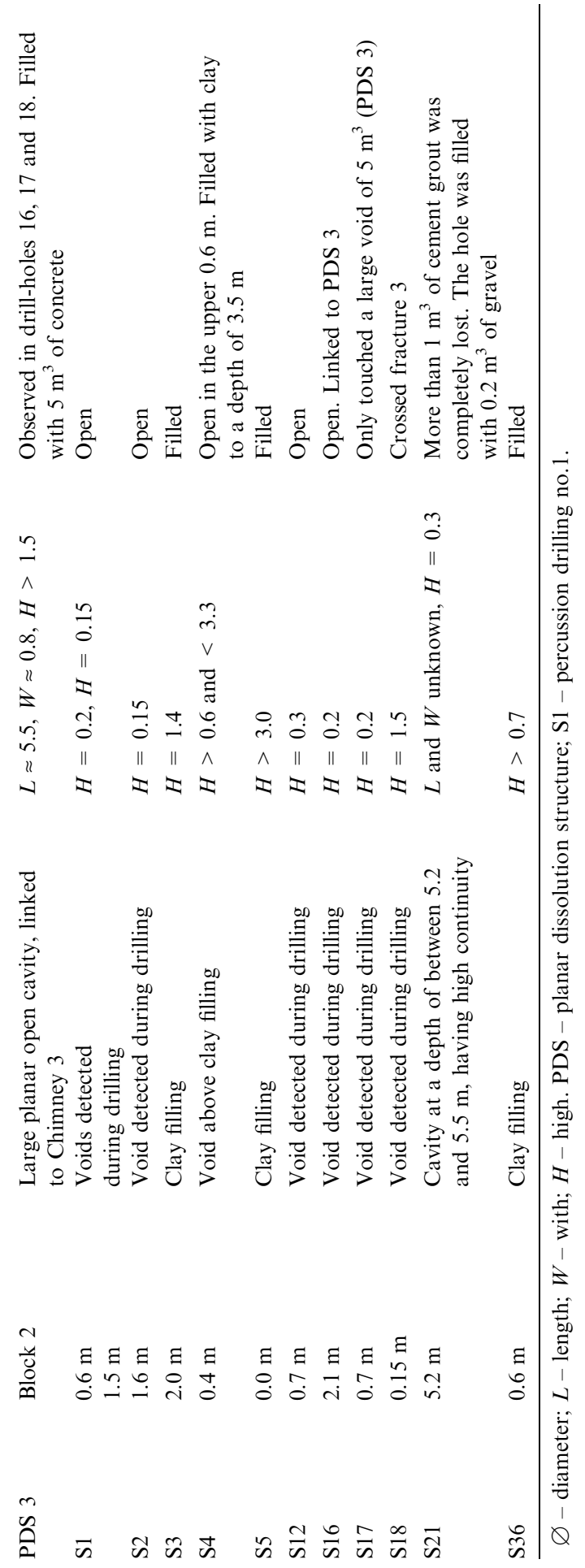


limestone was found in several drill-holes (2, 3, 4, 9, 12, 14 and 15). Drill-holes 3, 4 and 5 contained very plastic clay fillings that absorbed the energy of the pneumatic hammer, creating great difficulties and delays in the execution of the destructive drillings.

Drill-holes 1, 2, 4, 12, 16, 17 and 18 intersected karstic structures (Table 1). The karstic structures found in drill-holes 1, 2, 4 and 12 did not seem to have continuity. On drill-holes 16, 17 and 18 it was observed that the compressed air used to operate the hammer flowed out from the contiguous drill-holes and dissolution chimney. Drill-hole 18 encountered a cavity at depths of between $0.5 \mathrm{~m}$ and $1.3 \mathrm{~m}$. The observations on drill-holes 16,17 and 18 together with the surface observations revealed a large karstic structure (PDS 3) greatly affecting the foundations of the building.

\subsection{PHASE 3}

The reconnaissance in block 1 (area DEFGH) was only done when the construction in block 2 had already started. The main tasks done in phase 3 were: execution of 31 destructive drillings (nos. 19-49) in the location of the footings (Figure 4); footings excavation and mapping of exposed surfaces; dental cleaning of karstic structures filled with clay; filling of voids and drill-holes with concrete or granular material; footings reinforcement and construction of the foundation of the building in block 1 .

In the places where the excavations for the foundations were executed before drilling, it was necessary to refill these spaces. A filling thickness of between 0.45 and $1.0 \mathrm{~m}$, allowed obtaining a regular surface for the operation of the drilling equipment (drill-holes 26, 27, 33, 34, 35 and 36). During the execution of the destructive drillings, these fills that were dumped and were very loose, showed some heave around the drill-holes, due to the up-lift pressure of the compressed air used in the drilling operations.

The brown organic soil mixed with limestone tuffs was only found in drillings on the west side of block 1, due to the gentle slope to the west of this formation (Figures 3 and 4).

Drill-hole 36 contained very plastic clay fillings that absorbed the energy of the pneumatic hammer, creating great difficulties in the execution of the destructive drillings.

At drill-hole 21 between the depths of 5.2 and $5.5 \mathrm{~m}$, it was found a void that could not be filled with concrete because it was completely lost to the karstic system.

\section{Karstic Structures Found on Site}

\subsection{GENERAL ASPECTS}

The peculiar way the limestone tuffs formed, resulting from the precipitation of calcite around the vegetation or inorganic elements created a high porosity, and very 
permeable rock mass, where the percolation of water is intense, promoting the development of dissolution zones. Prior to human intervention a stream flowed over the ground, where the building was to be constructed. At present the stream artificially flows at an upper level, in the south limit of the construction site. The infiltration of the water from the stream and the rain, allowed the development of the karstic structures (e.g.: chimneys, planar dissolution structures, cavities, tubes). In Table 1 a summary of the main karstic structures identified during the site investigation are shown.

\subsection{DISSOLUTION CHIMNEYS}

The observed dissolution chimneys $(\mathrm{Ch})$ have circular shape, most frequently with a diameter around $0.1-0.15 \mathrm{~m}$. It was possible to verify that they usually link to deeper dissolution chambers located below. As an example we refer to the cavity P1, detected after the execution of pit P1, following a chimney tube of $0.12 \mathrm{~m}$ of diameter. In a similar way the opening of a pit in the place of chimney P2 revealed more cavities (cavities P2) partially filled with clay.

A few more chimneys were identified during the site investigation. It was observed that the chimney 3 was directly connected to the large planar dissolution structure no. 3. For chimney 4 we did not investigate its continuity because it was outside the construction area (Figure 4).

\subsection{PLANAR DISSOLUTION STRUCTURES}

The planar dissolution structures (PDS) have an important development, and are sub-vertical, slightly inclined to east, being illustrative the three structures named PDS 1, 2 and 3 (Figure 4). The walls of these planar structures were covered by karstic features resulting from the precipitation of calcite. We consider that these planar structures are the result of fractures that were enlarged by dissolution and that had posterior precipitation of calcite in the walls.

PDS 1 is the longer karstic structure found on site, having a visible extension around $15 \mathrm{~m}$. Its width, at the level of the foundation was between 0.15 and $0.5 \mathrm{~m}$. The geometry indicated that it is the result of the conjunction of two structures with different directions. This dissolution structure is clearly linked with other adjacent structures. Its reconnaissance was difficult because it was filled with very plastic brown clay.

PDS 2 was around $7.5 \mathrm{~m}$ in length, $0.5-1.0 \mathrm{~m}$ width and a height of up to $2.0 \mathrm{~m}$. This structure developed essentially in the unit of the cover soils, mixed with limestone tuffs. It was partially filled with clay, and a large extent of this structure was removed during the excavation operations.

PDS no. 3 was the last to be identified, and had the greatest consequences for the foundation of the building. It was $5.5 \mathrm{~m}$ long, $0.8 \mathrm{~m}$ wide and more than $1.5 \mathrm{~m}$ high, 
with a volume of about $5 \mathrm{~m}^{3}$. It was disclosed by the mechanical investigation (drillholes 16, 17 and 18).

\subsection{DISSOLUTION CAVITIES}

The dissolution cavities in the limestone tuffs showed variable dimensions and geometries, and were frequently linked to other dissolution structures. Some examples are cavity 1 located on the east side, underneath the place where chimney 1 was first identified. The excavation of pit 1 revealed a cavity, below the foundation level, with over two meters difference between the highest and the lowest points. The width of the cavity is variable from a few decimeters to more than $1.0 \mathrm{~m}$. The extent of the cavity was not clarified because it was partially filled with clay, reducing the accessibility. This cavity was linked to other adjacent karstic structures.

On the south face of the excavation several dissolution cavities were identified above the foundation level of the building. The most important was $0.5 \mathrm{~m}$ high by $1.2 \mathrm{~m}$ wide, had a very irregular shape and was in continuity with PDS 1. It is represented in Figure 3.

The excavation executed on pit 3 identified another dissolution cavity at a depth of more than $1.0 \mathrm{~m} \times 0.3 \mathrm{~m}$ high, which could not be completely evaluated because it was also filled with clay.

\section{Problems for the Foundations of the Building}

\subsection{GENERAL ASPECTS}

The first phase of investigation revealed that the visible karstic structures in the limestone tuffs were only a part of a larger set, which was not possible to observe in totality. Even if the entire surface of the tuff was well exposed it would not be possible to identify all the karstic structures because they develop below the interior of the limestone tuff.

Some of the problems that the karstification of the limestone tuffs could cause to the building under construction were:

- the collapse of the roof of the cavities or other dissolution structures, due to the increased load generated by the building and by the reduction in the thickness of the cover ground above the top of the dissolution structures;

- differential settlements between footings of the building due to the deformation or failure of the ground;

- high costs if these problems occur in a late phase of construction, or during the life time of the building;

- possibility of water inflow to the ground floor of the building, due to the percolation through the karstic system, during heavy rain or with the increase of the flow in the stream, located several meters above the basement. 


\subsection{REMEDIAL TREATMENT}

The first area to be treated in the foundation of the building was area ABCI. In this area, due to the schedule of the project, it was decided to continue the construction of the foundations, based on the surface survey, without any drilling. This decision was based in the fact that the karstic structures found in this small area of the block 2 could be well defined in the foundation platform, due to the low content of clay of the limestone tuffs.

The procedure followed to execute the remedial treatment of the foundation was, in general, the one described below.

Before the placement of the regularization concrete, all the soils were removed by dental cleaning, and when it was necessary the ground surface of the foundation was washed with a jet of water to allow a good identification of the karstic structures.

In the karstic structures filled with soils, dental cleaning was performed, at least $1 \mathrm{~m}$ below the lowest foundation level and the volume filled with concrete. The open karstic structures in the foundation area were filled with well compacted granular materials (gravel or aggregates), up to a depth of $1 \mathrm{~m}$ below the base of the foundation. The upper part was filled with concrete. To reduce the loss of concrete into the granular material a transition zone of fine sand could be used.

The open karstic structures outside the foundation area were filled with well compacted granular materials (gravel or aggregates). At the surface, the granular material could be covered by a geotextile or a layer of fine sand.

The data obtained at drill-holes 16,17 and 18 together with the surface observations revealed the larger open cavity close to the surface (PDS 3) affecting greatly the foundations of the building. To fill this cavity it was necessary to use $5 \mathrm{~m}^{3}$ of concrete. This cavity was located below an important foundation of the building, and if it had not been detected, and treated, serious problems would have arisen from the failure of the ground, due to the building weight.

At drill-hole 21 at the depths of between 5.2 and $5.5 \mathrm{~m}$, a void having high continuity with the karstic system was detected. More than $1 \mathrm{~m}^{3}$ of cement grout was completely lost when trying to fill this void. The drill hole was later filled with $0.2 \mathrm{~m}^{3}$ of gravel.

Most of the drill-holes were filled with cement grout. Figure 6 shows the relationship between the total length of the drill-hole and the ratio between the volume of the grout necessary to fill the drill-hole and the theoretical volume of the drill-hole. In most of the drill-holes the ratio is around 1, or slightly higher, while a few show much higher ratios, indicating the presence of cavities that were intersected by the drillholes. The records of the parameters of the drilling, mainly the drilling speed, allowed to identify the depth at what the cavities intersected, and are reported in Table 1.

\subsection{REINFORCEMENT OF THE FOUNDATION}

As the limestone tuffs formation deepen gently to the NW (around $5^{\circ}$ ), the foundation level in block 2 is entirely on the limestone tuffs. In block 1, the 


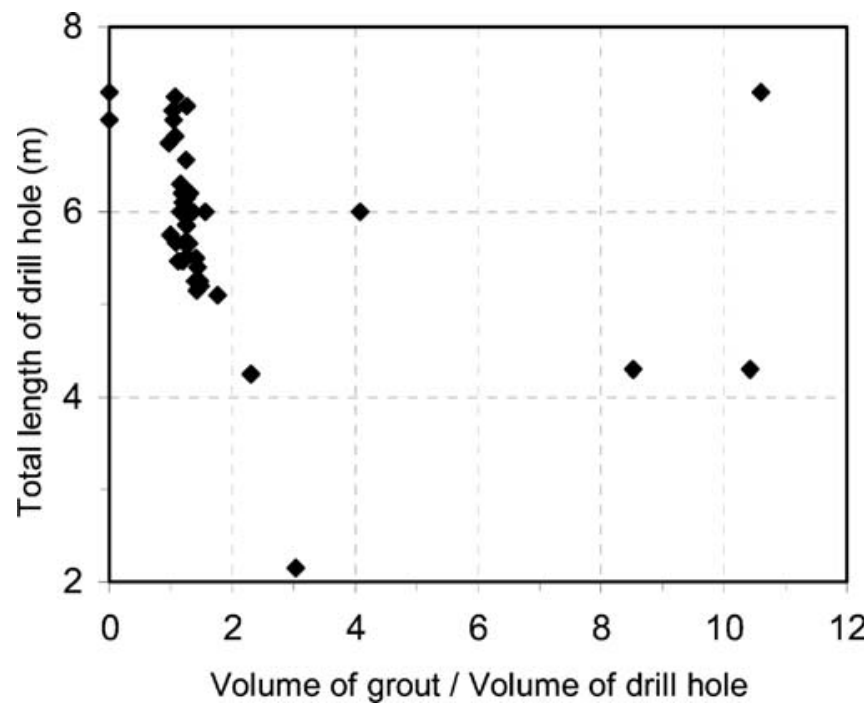

Figure 6. Relationship between the total length of the drill hole and the ratio: volume of grout poured to fill the drill hole / volume of drill hole.

limestone tuffs are only at the level of the foundation on one third of the block (Figures 3 and 4). This situation obliged to deepen the base of the footings in the NW part of block 1 in order to avoid the cover soils mixed with limestone tuffs, and to achieve similar foundation conditions in all block 1. Only the limestone tuffs showed the required bearing capacity for the pad foundations construction.

Based on the extent of the karstic structures found in the limestone tuffs, and on the experience reported by other authors (Fisher and Fisher, 1997; Mishu et al., 1997) it was considered necessary to reinforce the foundation. The treatment solutions included: (a) dental cleaning and filling with concrete and granular material of every dissolution void at the level of the foundation; (b) reinforcement of the footings and structure of the building with more steel; (c) adding a continuous foundation beam holding together the pad foundations. It was considered that the foundation after reinforcement should resist an empty span of $3 \mathrm{~m}$, which could result from the collapse of an undisclosed karstic structure. The span of $3 \mathrm{~m}$ was considered suitable in relation with the dimensions of the identified karstic structures being similar to the one suggested by Fischer and Fischer (1997).

To reduce the risk of further instability in the foundation it was considered adequate to drain all the water from seepage, rain, gardening or even accidental sewage rupture. To achieve this objective a drain was used at the bottom of the perimeter retaining wall of the excavation and also a drainage blanket below the foundation. 


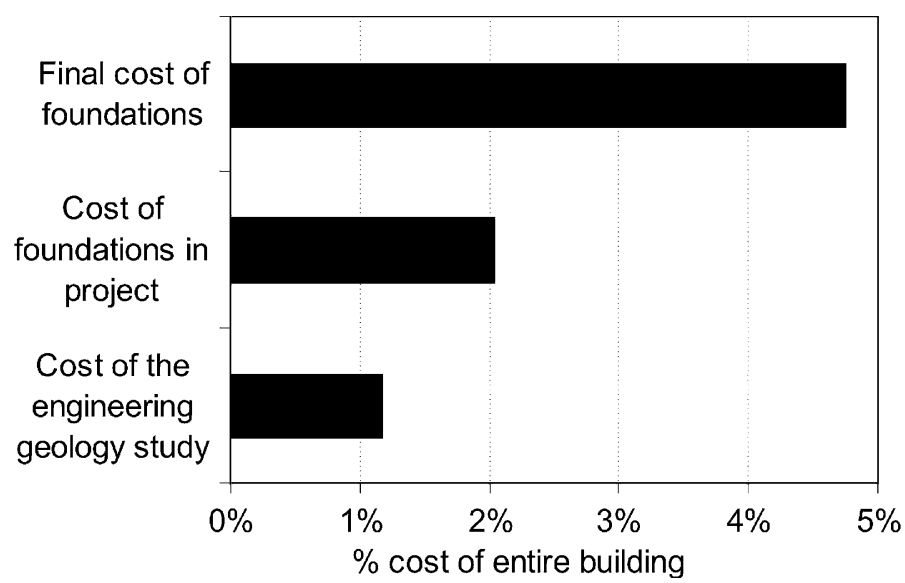

Figure 7. Percentage of cost of the foundation and engineering geology study, related with the cost of the building.

\section{Cost analysis}

The cost of the engineering geology study and site investigation, including the mechanical drillings was only $1.2 \%$ of the total construction cost.

Considering the cost of the foundations in relation to the total cost of the building, it increased from the $2 \%$ predicted in the original design, to $4.8 \%$ after construction (Figure 7). The total costs for the construction of the building was $€ 870000$.

\section{Final remarks}

The limestone tuffs are formed by the precipitation of calcite around materials, like clay, gravel, sand or even plants. This complex origin creates the condition for a heterogeneous and unpredictable material, presenting important geotechnical problems for the construction of engineering structures.

The engineering geology study permitted the identification of a few karstic structures and clarified the main problems that could arise from their presence and assisted on the selection of the most suitable procedures to overcome construction site problems.

The joint analysis of all the geological, geotechnical and engineering elements led to the selection and confirmation of the solutions for the foundations and building structure, which were considered suitable to overcome the karstification problems on site.

The building did not show any signs of damage to date.

\section{Acknowledgments}

The authors acknowledge the financial support provided by Fundação para a Ciência e Tecnologia through the research project POCTI/ECM/38444/2001, co 
participated by FEDER; Centro de Geociências of the University of Coimbra; Instituto Pedro Nunes, Coimbra. The authors also thank Cáritas and Edicontrole for their permission to publish the results.

\section{References}

Fischer, J. A. and Fischer, J. J. (1997) Wyndham Farms - a karst case study. In The Engineering Geology and Hydrogeology of Karst Terranes (edited by Beck and Stephensen)., Balkema, Rotterdam, pp. 287-292.

Gaida, R. and Radtke, U. (1983) Datation des tufs calcaires quaternaires du Baixo Alentejo par les méthodes Th/U et ESR. Finisterra, Lisboa, XVIII, 35, pp. 107-111.

Mishu, L. P., Godfrey, J. D. and Mishu, J. R. (1997) Foundation remedies for residential construction over karst limestone in Nashville, Tenessee. In The Engineering Geology and Hydrogeology of Karst Terranes (edited by Beck and Stephensen), Balkema, Rotterdam, pp. 319-327.

Quinta Ferreira, M. (1998) Estudo geológico-geotécnico dos terrenos de fundação do Centro Comunitário de Nossa Senhora dos Milagres - Cernache. Edicontrole, Lda, Coimbra, Portugal (in Portuguese).

Quinta Ferreira, M. (1999) Relatório das sondagens e do acompanhamento das fundações do Centro Comunitário de Nossa Senhora dos Milagres - Cernache. Edicontrole, Lda, Coimbra, Portugal (in Portuguese).

Soares, A. F., Cunha, L. and Marques, J. F. (1997) Les tufs calcaires dans la région du Baixo Mondego (Portugal). Les Tufs de Condeixa. Présentation Générale. Études de Géographie Physique, Travaux 1997 - Supplément au No. XXVI. Colloque hispano-français - Milieux carbonatés continentaux. Séville, pp. 55-58. 